\title{
TINGKAT KERENTANAN TERHADAP PERUBAHAN IKLIM PADA DESA - DESA SEKITAR TAMAN NASIONAL KERINCI SEBLAT (TNKS) DI KECAMATAN PINANG BELAPIS KABUPATEN LEBONG PROVINSI BENGKULU
}

\author{
Fretty Anggreani $W^{l)}$, Agus Susatya ${ }^{2)}$, Syafrin Tiaif ${ }^{2)}$ \\ ${ }^{1)}$ Dinas Pertanian dan Perikanan Kabupaten Lebong, \\ , ${ }^{2)}$ Jurusan Kehutanan, Fakultas Pertanian,Universitas Bengkulu, Email : \\ frettyanggreanippl@gmail.com
}

\begin{abstract}
ABSTRAK
Dampak perubahan iklim mempengaruhi sumber penghasilan penduduk desa-desa sekitar TNKS. Penurunan produktivitas pertanian menyebabkan penduduk melakukan upaya ektensifikasi, sehingga lahan hutan menjadi alternatif perubahan lahan untuk perladangan dan pertambangan. Penelitian ini bertujuan :1) mengetahui tingkat kerentanan desa-desa sekitar TNKS terhadap perubahan iklim, 2) mengetahui pemetaan tingkat kerentanan tersebut dan 3) mengetahui upaya adaptasi terhadap perubahan iklim. Hasil penelitian menunjukkan bahwa desa yang termasuk kategori sangat rentan terhadap perubahan iklim adalah Desa Ketenong I dan Desa Ketenong II $(28,60 \%)$, Desa yang rentan adalah Desa Ketenong Jaya (14,20\%), Desa yang agak rentan adalah Desa Air Kopras dan Desa Sebelet Ulu $(28,60 \%)$ serta Desa yang tidak rentan yaitu Desa Bioa Putiak dan Desa Tambang Saweak (28,60\%). Upaya adaptasi terhadap perubahan iklim dapat dilakukan dengan memperbaiki saluran irigasi dari sederhana dan tadah hujan menjadi irigasi teknis dan semi teknis serta pembangunan embung-embung, mengurangi kepadatan penduduk, memperluas diversifikai sumber penghasilan (non pertanian), memperbaiki infrastruktur (fasilitas kesehatan, jalan, sarana pemasaran, sarana dan prasarana pertanian) serta penguatan kelembagaan petani.
\end{abstract}

Kata kunci : Kemampuan Adapasi, Perubahan iklim, Potensial Dampak, Taman Nasional Kerinci Sebelat

\section{PENDAHULUAN}

Kawasan Taman Nasional Kerinci Sebelat (TNKS) Wilayah Resort Lebong yang memiliki luas \pm 126.321 $\mathrm{Ha}$ berbatasan dengan 7 desa administrasi pemerintahan Kecamatan Pinang Belapis yaitu desa Air Kopras, Desa Bioa Putiak, Desa Tambang Sawah, Desa Ketenong I, Desa Ketenong II, Desa Ketenong Jaya dan Desa Sebelat Ulu. Menurut Peraturan Pemerintah Kabupaten Lebong Nomor 14 Tahun 2012, Desa-Desa di Sekitar TNKS

Kecamatan Pinang Belapis merupakan kawasan bencana alam yakni tanah longsor. BPBD Provinsi Bengkulu mencatat bahwa di
Kabupaten Lebong telah terjadi kejadian bencana tanah longsor sebanyak 24 kali selama kurun waktu Januari sampai Desember dari tahun 2012 sampai tahun 2016. Jika ditinjau dari aspek biofisik, kejadian bencana tanah longsor ini sendiri disebabkan oleh curah hujan yang semakin bertambah dengan intensitas cukup tinggi (iklim ekstrim) sebagai akibat dampak dari perubahan iklim.

Dampak perubahan iklim juga mempengaruhi sumber penghasilan penduduk desa-desa sekitar TNKS. Secara keseluruhan sektor usahatani (perkebunan atau persawahan) masih mendominasi sumber pendapatan dalam rumah tangga di desa-desa sekitar kawasan TNKS Kabupaten Lebong 
Provinsi Bengkulu (Sukiyono, 2014). Secara kumulatif, jumlah rumah tangga yang berkerja di sektor pertanian lebih dari $80 \%$. Sektor pekerjaan lain yang juga banyak dimasuki oleh rumah tangga adalah sektor pertambangan yang menyerap lebih dari $11 \%$ rumah tangga. Sektor tambang yang banyak dimasuki oleh kepala rumah tangga adalah tambang emas tradisional, serta sektor galian pasir dan batu (Sukiyono, 2013). Saat ini sektor pertambangan batu bara menjadi primadona selain penambangan emas tradisional di kecamatan ini sejak dibukanya tambang batu bara di Desa Ketenong II yang dikelola oleh PT. Jambi Resaurces.

Di sektor pertanian, dampak perubahan iklim ditandai dengan penurunan produktivitas tanaman pangan dan hortikultura dan peningkatan hama dan penyakit pengganggu tanaman. Penurunan produktivitas pertanian menyebabkan penduduk melakukan upaya ektensifikasi, sehingga lahan hutan menjadi alternatif perubahan lahan untuk perladangan dan pertambangan.

Laju kerusakan kawasan Taman Nasional Kerinci Sebelat di Propinsi Bengkulu sangat tinggi (Walhi Bengkulu 2008) dalam (Sukiyono,2013). Walhi Bengkulu melaporkan bahwa awal tahun 2004, dari 340.575 Ha kawasan yang masuk dalam wilayah administrasi propinsi Bengkulu 36,27 \% (123.534,58 ha) telah rusak parah (kondisi non-hutan). Ada dugaan bahwa hutan ini secara berangsur telah dialih-fungsikan oleh masyarakat menjadi berbagai bentuk penggunaan lahan lain seperti pemukiman dan pekarangan, pertanian, kebun dan perkebunan.

Dari uraian di atas, semakin menunjukkan bahwa desa-desa di sekitar TNKS rentan terhadap dampak perubahan iklim baik dari aspek lingkungan, sosial dan ekonomi. Selain itu, belum ada kajian mengenai tingkat kerentanan desa terhadap perubahan iklim. Oleh karenanya dirasa perlu untuk melakukan kajian mengenai tingkat kerentanan desa-desa sekitar TNKS terhadap perubahan iklim agar dapat menjawab pertanyaan-pertanyaan sebagai berikut :

1. Bagaimana tingkat kerentanan terhadap perubahan iklim pada desadesa sekitar kawasan TNKS

2. Bagaimana pemetaan tingkat kerentanan terhadap perubahan iklim pada desa-desa sekitar kawasan TNKS

3. Bagaimanakah alternatif adaptasi terhadap perubahan iklim pada desadesa sekitarkawasan TNKS

Adapun Tujuan dari penelitian ini adalah

1) Untuk mengetahui tingkat kerentanan terhadap perubahan iklim pada desa-desa sekitar kawasan TNKS

2) Untuk memetakan tingkat kerentanan terhadap perubahan iklim pada desa-desa sekitar kawasan TNKS

3) Untuk memberikan alternatif adaptasi terhadap perubahan iklim pada desa-desa sekitar kawasan TNKS

\section{METODE PENELITIAN}

Penelitian akan dilakukan di 7 desa sekitar kawasan TNKS di Kecamatan Pinang Belapis Kabupaten Lebong yaitu Desa Air Kopras, Desa Bioa Putiak, Desa Tambang Sawah, Desa Ketenong I, Desa Ketenong II, Desa Ketenong Jaya, dan Desa Seblet Ulu.

Waktu penelitian dilaksanakan selama enam bulan dan dibagi menjadi empat tahap, yaitu tahap persiapan, pengumpulan data, pengolahan data, penyelesaian. Tahap persiapan dilaksanakan sampai Juli 2017. 
Pengumpulan data dilaksanakan pada Juli-September 2017. Pengolahan data dilaksanakan September-November 2017. Dan tahap penyelesaian dilaksanakan November- Desember 2017.

Metode pengumpulan data adalah wawancara mendalam terhadap responden maupun tim ahli dan pengisian Quesioner

Teknik sampling yang digunakan adalah random sampling dengan jumlah yang sama setiap desa. Responden dipilih dari 7 (tujuh) desa sekitar TNKS, Kecamatan Pinang Belapis, Kabupaten Lebong. Hasil dari teknik sampling terpilih $70 \mathrm{KK}$ yang menjadi responden.

Kegiatan untuk mengidentifikasi adanya perubahan iklim lokal dilakukan dengan dua pendekatan yaitu analisis kecenderungan terhadap perubahan pola hujan dan studi persepsi masyarakat desa sekitar TNKS, Kecamatan Pinang Belapis, Kabupaten Lebong.

Teknik analisis data yang digunakan adalah pembobotan dan skoring. Teknik pembobotan yang dilakukan menggunakan teknik pemeringkatan oleh para ahli yang berjumlah 20 orang terdiri dari 2 orang akademisi, 2 orang dari Seksi Pengelolaan Taman Nasional Wilayah VI, 1 orang dari KPHL Resort Lebong, 2 orang dari Dinas Pertanian dan Perikanan Kabupaten Lebong, 1 orang dari Bappeda Kabupaten Lebong, 3 orang dari Dinas LHK Provinsi Bengkulu, 3 orang dari BPDAS Provinsi Bengkulu, 2 orang dari KPHL Bukit Daun, 2 Orang dari BKSDA Provinsi Bengkulu, 1 orang dari Lembaga Sosial Masyarakat (LSM) "Akar" dan 1 orang dari LSM "Ulayat".

Skoring dilakukan terhadap subindikator dari setiap indikator keterpaparan, sensitivitas dan kemampuan adaptasi. Data yang digunakan untuk skoring setiap sub indikator dalam penelitian ini ini bersumber dari profile desa-desa sekitar TNKS, Kecamatan Pinang Belapis, Kabupaten Lebong. Nilai skoring dibuat dalam bentuk persentase.

Setelah dilakukan pembobotan dan scoring maka hasil yang diperoleh kemudian dilakukan perkalian sehingga dihasilkan indeks kerentanan masingmasing indikator di setiap desa.

Indeks potensial dampak (IPI) dan kemampuan adaptif (IAC) yang telah dihasikan kemudian dinormalisasi. Lebih lanjut, kombinasi IPI dan IAC dikelompokkan menggunakan matrik topologi kerentanan mengikuti Sariffuddin (2017)

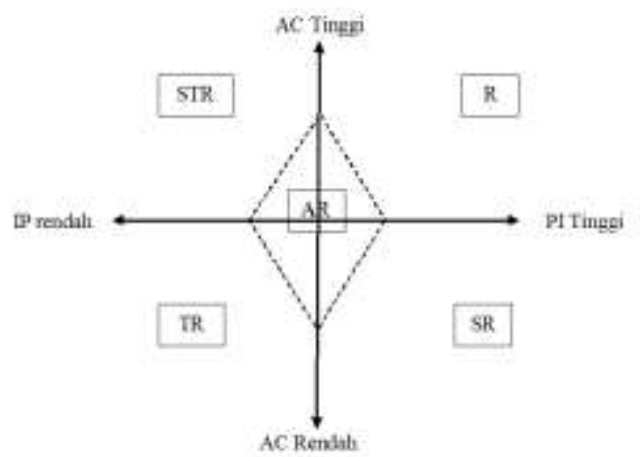

Gambar 1. Tipologi Kerentanan (Sumber : Sariffuddin (2017)

Keterangan :

STR : Sangat tidak rentan

TR : Tidak rentan

AR : Agak rentan

R : Rentan

SR : Sangat rentan

Hasil analisis tingkat kerentanan desa-desa sekitar TNKS di Kecamatan Pinang Belapis, Kabupaten Lebong kemudian dilanjutkan dengan pembuatan peta tingkat kerentanan desa. Peta yang dihasilkan adalah peta tingkat kerentanan desa, peta potensial dampak desa dan peta kemampuan adaptasi desa-desa sekitar TNKS, Kecamatan Pinang Belapis, Kabupaten Lebong. 
Hasil klasifikasi indeks potensi dampak (IPI) dan Indeks kemampuan adaptasi (IAC) tersaji pada Tabel.1

Tabel 1. Klasifikasi indeks potensial dampak dan indeks kemampuan adaptasi

\begin{tabular}{lll}
\hline Indeks & Nilai Rentang & Kategori \\
\hline Potensial & $18,737-19,811$ & Sangat rendah \\
Dampak & $>19,811-20,882$ & Rendah \\
& $>20,882-21,953$ & Sedang \\
& $>21,953-23,024$ & Tinggi \\
& $>23,024-24,095$ & Sangat Tinggi \\
\hline Kemampuan & $10,381-10,5798$ & Sangat rendah \\
Adaptasi & $>10,5798-10,7786$ & Rendah \\
& $>10,7786-10,9774$ & Sedang \\
& $>10,9774-11,1762$ & Tinggi \\
& $>11,1762-11,375$ & Sangat Tinggi \\
\hline
\end{tabular}

\section{HASIL DAN PEMBAHASAN Perubahan Iklim}

Analisis kecenderungan pola curah hujan menggunakan data pos hujan BPP Tes, Kecamatan Lebong Selatan, Kabupaten Lebong yang dimiliki BMKG, dikarenakan ketersediaan data yang memungkinkan dilakukan analisis dibandingkan dengan pos hujan di Kecamatan Pinang Belapis dan pos hujan Tunggang. Pada penelitian ini, digunakan data curah hujan tahunan 1987-2016.

Analisis curah hujan tahunan selama 30 tahun (1987-2016) pada desa-desa sekitar TNKS, Kecamatan Pinang Belapis, Kabupaten Lebong menunjukkan terjadinya kecenderungan penurunan curah hujan. Pada tahun 1996-1997 terjadi El-Nino dimana musim kemarau merata sepanjang tahun. Pada saat itu, tidak terjadi hujan sama sekali (curah hujan =0). Pada tahun 1989, 1990, 1998 dan 2010 terjadi La- Nina dengan jumlah curah hujan tinggi. Jumlah curah hujan tinggi ini masing-masing $4683 \mathrm{~mm} /$ tahun, $4296 \mathrm{~mm} /$ tahun, $4061 \mathrm{~mm} /$ tahun dan $3717 \mathrm{~mm} /$ tahun.

Dari data terlihat bahwa setelah terjadinya musim kemarn yang berkepanjangan (pada tahun 19961997), terjadi hujan dengan intensitas curah hujan sangat tinggi (pada tahun
1998). Intensitas curah hujan yang sangat tinggi ini membuat tanah menjadi sangat gembur sehingga berpotensi menyebabkan terjadinya longsor di desa-desa sekitar TNKS, Kecamatan Pinang Belapis, Kabupaten Lebong

Untuk mengidentifikasi adanya perubahan iklim, maka analisa komposit dilakukan dengan mengelompokkan curah hujan periode 10 tahunan yaitu periode 1987-1996 dan 1997-2006 sebagai kondisi baseline dan periode 2007-2016 yang mewakili kondisi sekarang.

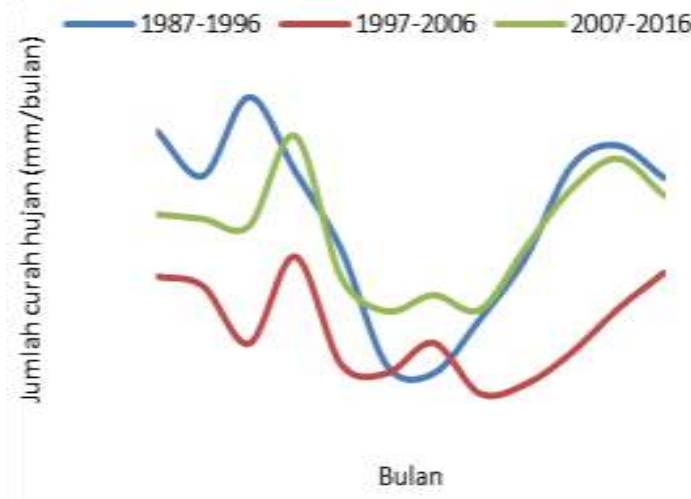

Grafik 1 Jumlah curah hujan bulanan periode 1986-2016 Pos Hujan BPP Tes, Kecamatan Lebong Selatan, Kabupaten Lebong. Periode I (1987-1996),

Periode II (1997-2006) dan Periode III (2007-2016

Grafik 1 menggambarkan pola curah hujan sepanjang tahun 1987 sampai dengan 2016. Grafik ini menunjukkan bahwa pada musim penghujan (Bulan September sampai April) ada kecenderungan penurunan curah hujan di bawah rata-rata pada periode II dan III dibandingkan dengan periode I. Sedangkan pada musim kering, curah hujan pada periode II dan III lebih tinggi daripada periode I terjadi pada bulan Juni sampai Bulan Agustus. Hal ini menunjukkan kecenderungan penurunan curah hujan pada musim hujan dan musim kemarau. 
Grafik 1 menunjukkan terjadi pergeseran puncak curah hujan di bulan Maret periode 1987-1996 menjadi bulan April pada periode 1997-2006 dan 2007-2016. Sementara puncak musim kering juga mengalami pergeseran dari bulan Juni-Juli pada periode 1986-1995 menjadi bulan Agustus pada periode 1996-2006 dan 2007-2016.

Mundurnya musim kemarau juga dirasakan di wilayah Provinsi Sumatera Selatan pada tahun 2010 (Sriwijaya post, 2010).

Dari 70 orang responden, $89 \%$ diantaranya telah merasakan dampak terjadinya perubahan iklim. Sebagian besar responden ini berprofesi sebagai petani. Sedangkan 11\%-nya menyatakan tidak tahu tentang terjadinya perubahan iklim. Responden yang menyatakan tidak tahu ini berprofesi sebagai penambang emas tradisional. Menurut mereka, kegiatan pertambangan tidak ada kaitannya dengan perubahan iklim karena mereka bekerja pada bawah tanah yang tidak terpapar oleh cuaca dan iklim.

Menurut sebagian besar petani dampak perubahan iklim dirasakan terhadap penurunan produksi komoditas tanaman pertanian yaitu tamanan padi sawah dan tanaman kopi

Hasil penelitian menunjukkan bahwa curah hujan dan kekeringan mempengaruhi produksi tanaman padi sawah dan tanaman kopi. Curah hujan yang lebih lebat dan kekeringan menyebabkan terjadinya penurunan produksi tanaman padi sawah sebesar $25 \%$ dan $80 \%$.

Hal ini lebih besar dari penelitian Irawan (2006) yang menyatakan bahwa El-nino (musim kemarau) yang terjadi pada tahun 1997-2010 menimbulkan dampak penurunan produksi padi sebesar 4,08. Terjadinya La-Nina pada kurun waktu yang sama menimbulkan dampak positif dalam hal ini peningkatan produksi padi sekitar $1,78 \%-4,29 \%$.

Masyarakat desa sekitar TNKS, Kecamatan Pinang Belapis, Kabupaten Lebong memiliki persepsi bahwa curah hujan yang lebat dan kekeringan dapat menyebabkan terjadinya penurunan produksi kopi sebesar 10\% dan $40 \%$. Hal ini jauh lebih kecil dari penelitian Supriadi (2014) yang menyatakan bahwa akibat El-Nino mengakibatkan produksi kopi menurun sebesar $34,79 \%$, begitu juga curah hujan diatas $100 \mathrm{~mm}$ per bulan akibat La-Nina mengakibatkan produksi kopi menurun $98,5 \%$.

\section{Tingkat kerentanan dan upaya adaptasi terhadap perubahan iklim}

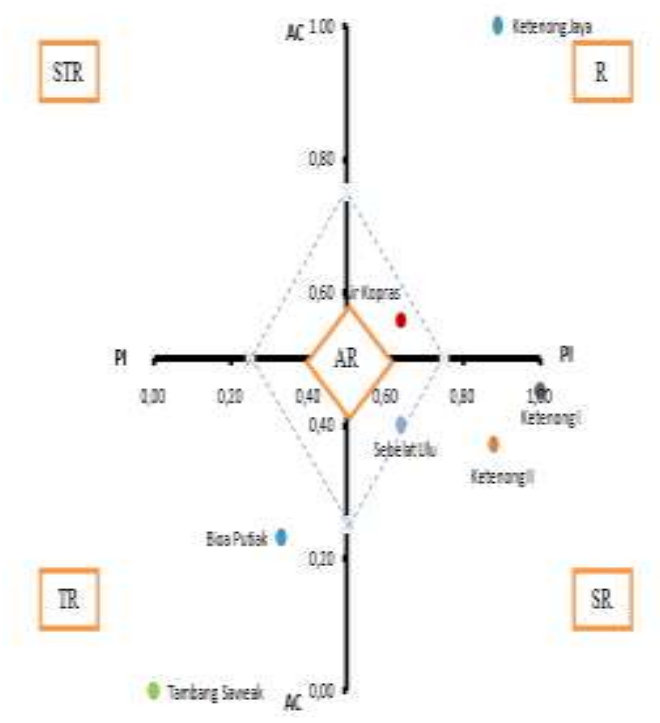

Gambar 2. Diagram Cartesius Tingkat Kerentanan DesaDesa Sekitar TNKS, Kecamatan Pinang Belapis, Kabupaten Lebong. PI adalah Potensial Dampak dan AC adalah Kemampuan Adaptif

Diagram di gambar 2 memperlihatkan bahwa Desa Ketenong I dan Ketenong II termasuk kategori sangat rentan terhadap perubahan iklim. Desa yang termasuk kategori rentan terhadap perubahan iklim yaitu Desa Ketenong Jaya. Desa Air Kopras dan Desa Sebelet Ulu termasuk kategori agak rentan terhadap perubahan iklim. 
Sedangkan desa yang termasuk kategori tidak rentan terhadap perubahan iklim yaitu Desa Bioa Putiak dan Desa Tambang Saweak.

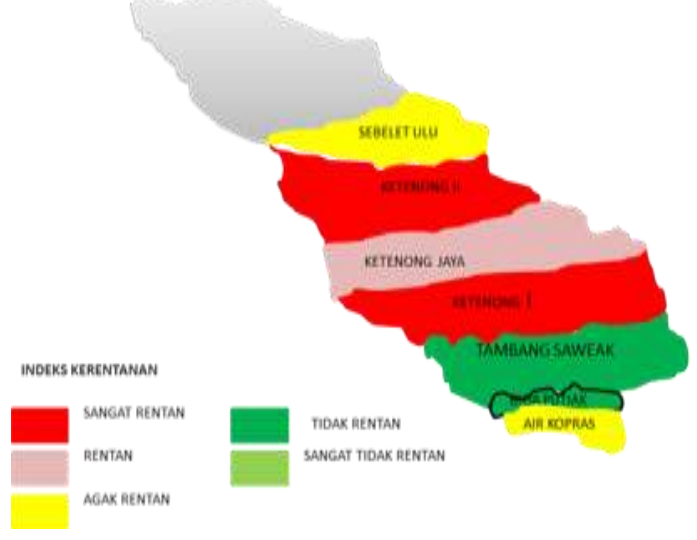

Gambar 3. Peta tingkat kerentanan desa pada desadesa sekitar TNKS, Kecamatan Pinang Belapis, Kabupaten Lebong

Dari total jumlah desa sekitar TNKS di Kecamatan Pinang Belapis, Kabupaten Lebong, desa yang termasuk kategori sangat rentan $(28,6 \%)$, kategori rentan $(14,2 \%)$, kategori agak rentan $(28,6 \%)$ dan kategori tidak rentan $(28,6 \%)$.

Tabel 2. Indeks Keterpaparan, Sensitivitas, Potensial Dampak (PI) dan Kemampuan Adaptif (AC) desa-desa sekitar TNKS, Kecamatan Pinang Belapis, Kabupaten Lebong

\begin{tabular}{|c|c|c|c|c|}
\hline Den & $\begin{array}{c}\text { Taddss } \\
\text { Ketapepum }\end{array}$ & $\begin{array}{c}\text { Indiks } \\
\text { Sesitivinat }\end{array}$ & $\begin{array}{c}\text { Iaddhs } \\
\text { Pstasisd } \\
\text { Dumpak (PI) }\end{array}$ & $\begin{array}{c}\text { Iodebs } \\
\text { Kemimpaun } \\
\text { Adaptif(AC) }\end{array}$ \\
\hline Air Koprus & 15,936 & 6205 & 22,141 & 10,845 \\
\hline Bice Patiak & 14,304 & 6,181 & 20,485 & 10,572 \\
\hline Tumbang Satreak & 12,758 & 5979 & 18,737 & 10,381 \\
\hline Retetos, I & 17,760 & 6336 & 24,695 & 10,313 \\
\hline Reseras Thy & 17,454 & 6,042 & 23,495 & 11,375 \\
\hline Keretorg II & 16,747 & 6,703 & 23,451 & 10,731 \\
\hline Sebelys Unu & 15,868 & 6.294 & 22,162 & 10,720 \\
\hline
\end{tabular}

Dari tabel 2, Desa Ketenong I dan Ketenong II termasuk kategori sangat rentan terhadap perubahan iklim. Kedua desa ini memiliki indeks potensial dampak (IPI) tinggi dan indeks kemampuan adaptasi (IAC) relatif tinggi. Desa Ketenong Jaya termasuk kategori rentan terhadap perubahan iklim. Desa Ketenong Jaya ini memiliki indeks potensial dampak (IPI) yang tinggi dan indeks kemampaun adaptasi (IAC) yang lebih tinggi dibanding desadesa lain. Sementara itu, Desa Sebelat
Ulu dan Air Kopras termasuk kategori agak rentan terhadap perubahan iklim. Desa Sebelet Ulu dan Desa Air Kopras ini memiliki indek potensial dampak (IPI) dan indeks kemampuan adaptasi (IAC) relatif tinggi. Sedangkan, Desa Bioa Putiak dan Tambang Saweak termasuk katogori tidak rentan terhadap perubahan iklim. Kedua Desa ini memiliki indek potensial dampak (IPI) dan indeks kemampuan adaptasi (IAC) yang rendah.

\section{Potensial Dampak (PI)}

\section{Keterpaparan}

Dari total desa-desa sekitar TNKS Kecamatan Pinang Belapis, Kabupaten Lebong, desa yang memiliki indeks potensial dampak (IPI) sangat tinggi $(42,9 \%)$, tinggi $(28,6 \%)$, rendah $(14,25 \%)$ dan sangat rendah $(14,25 \%)$.

Berdasarkan indeks potensial dampak, Desa Ketenong I $(24,095)$ memiliki indeks potensial dampak yang paling tinggi, diikuti oleh Desa Ketenong Jaya $(23,495)$, Ketenong II $(23,451)$, Desa Sebelet Ulu $(22,162)$ dan Desa Air Kopras $(22,141)$. Desa yang memiliki indeks potensial dampak (IPI) yang rendah adalah Desa Bioa Putiak (20,485). Desa yang memiliki indeks potensial dampak (IPI) paling rendah adalah Desa Tambang Saweak $(18,737)$ seperti pada gambar 4

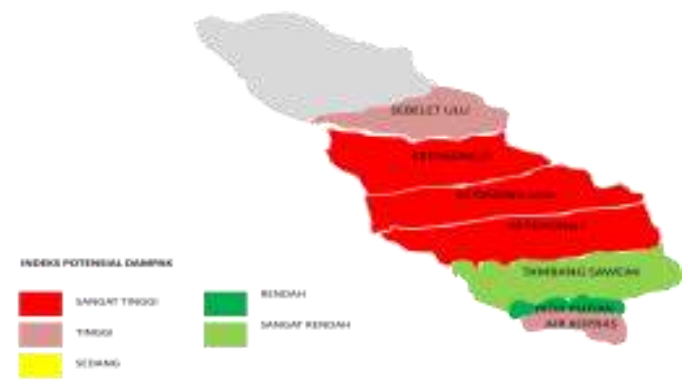

Gambar 4. Peta indeks potensial dampak (IPI) pada desa-desa sekitar TNKS, Kecamatan Pinang Belapis, Kabupaten Lebong 
Indeks potensial dampak (IPI) suatu desa terdiri dari indeks keterpaparan dan indeks sensitivitas suatu desa. Tinggi atau rendahnya indeks potensial dampak suatu desa tergantung dari nilai indeks keterpaparan dan sensitivitasnya.

Berdasarkan indeks keterpaparan, Desa Ketenong I memiliki indeks keterpaparan $(17,760)$ yang lebih tinggi dibandingkan dengan desa-desa yang lain, diikuti Desa Ketenong Jaya $(17,454)$, Desa Ketenong II $(16,747)$, Desa Air Kopras $(15,936)$ dan Desa Sebelet Ulu $(15,868)$. Desa yang memiliki indeks keterpaparan yang rendah adalah Desa Bioa Putiak $(14,304)$. Desa Tambang Saweak memiliki indeks keterpaparan $(12,758)$ yang paling rendah dibandingkan dengan desa-desa lainnya.

Desa Bioa Putiak dan Tambang Saweak termasuk kategori tidak rentan (TR) terhadap perubahan iklim. Kedua desa ini memiliki indeks keterpaparan yang lebih rendah dibandingkan dengan desa-desa lainnya. Indeks keterpaparan yang lebih rendah ini berasal dari indikator tipe sawah, jumlah petani dan sumber pendapatan utama.

Desa Sebelet Ulu memiliki posisi tingkat kerentanan yang rawan. Kerawanan ini disebabkan karena Desa Sebelet Ulu memiliki tipe sawah yang terdiri dari tipe sawah sederhana dan tadah hujan. Tipe sawah sederhana dan tadah hujan ini sangat tergantung dari air hujan (Agustine, 2018).

Desa Air Kopras juga memiliki indeks keterpaparan relatif tinggi yang disebabkan tingkat kelerengan desa (100\%). Menurut Kementrian Lingkungan Hidup, GTZ dan WWF (2010) Semakin tinggi persentase kelerengan (slope) suatu tempat berarti tempat tersebut semakin rentan terhadap perubahan iklim. Hal ini disebabkan karena potensi bahaya longsor atau erosi yang sangat tinggi pada desa ini saat terjadi frekuensi dan curah hujan yang tinggi.

Jika tidak ada intervensi mitigasi, maka Desa Sebelet Ulu dan Air Kopras akan jatuh ke kategori rentan (R) dan sangat rentan (SR) terhadap perubahan iklim. Desa Sebelet Ulu dan Air Kopras dapat berubah dari kategori agak rentan menjadi tidak rentan (TR) dan sangat tidak rentan (STR) dengan melakukan perbaikan pada tipe sawah sederhana dan tadah hujan menjadi tipe sawah irigasi teknis dan semi teknis.

Desa Ketenong Jaya merupakan desa yang rentan (R) terhadap perubahan iklim. Desa ini memiliki indeks keterpaparan yang tinggi. Indeks keterpaparan yang tinggi ini berasal dari indikator sumber pendapatan utama, jumlah petani, dan lokasi desa.

Untuk mengurangi tingkat kerentanan Desa Ketenong Jaya dari kategori rentan (R) menjadi sangat tidak rentan (STR) maka perlu dilakukan perbaikan tipe sawah dari dominan tipe sawah sederhana dan tadah hujan menjadi tipe sawah semi teknis dan teknis.

Desa Ketenong I dan Ketenong II merupakan desa sangat rentan terhadap perubahan iklim. Kedua desa ini memiliki indeks keterpaparan yang tinggi. Indeks keterpaparan yang tinggi ini berasal dari indikator tata guna lahan, tipe sawah dan jumlah petani.

Untuk mengurangi tingkat kerentanan Desa Ketenong I dan Ketenong II dari kategori sangat rentan (SR) menjadi agak rentan (AR) dan tidak rentan (TR) maka perlu dilakukan perbaikan tipe sawah dari dominan tipe sawah sederhana dan tadah hujan menjadi tipe sawah semi teknis dan teknis.

\section{Sensitivitas}

Berdasarkan indeks sensitivitas, Desa Ketenong II memiliki indeks 
sensitivitas yang lebih tinggi (6,703), diikuti oleh Desa Ketenong I (6,336), Desa Sebelet Ulu (6,294), Desa Air Kopras $(6,205)$ dan Desa Bioa Putiak $(6,181)$. Desa yang memiliki indeks sensitivitas yang paling rendah adalah Desa Ketenong Jaya $(6,042)$ dan Tambang Saweak $(5,979)$.

Desa Bioa Putiak dan Tambang Saweak termasuk kategori tidak rentan terhadap perubahan iklim. Kedua Desa ini memiliki indeks sensitivitas yang rendah. Desa Bioa Putiak dan Desa Tambang Saweak memiliki indeks sensitivitas yang rendah pada indikator IP padi sawah

Desa Sebelet Ulu dan Air Kopras termasuk kategori agak rentan terhadap perubahan iklim. Kedua desa ini memiliki indeks sensitivitas yang relatif tinggi. Desa Sebelet ulu memiliki indeks sensitvitas relatif tinggi yang berasal dari indikator IP padi sawah dan produksi padi sawah.

Desa Air Kopras memiliki indeks seinsitivitas relatif tinggi yang berasal dari indikator kepadatan penduduk. Desa Air Kopras memiliki kepadatan penduduk yang relatif tinggi (27,44 Jiwa/ $/ \mathrm{Km}^{2}$ ). Kepadatan penduduk di Desa Air Kopras sedikit lebih rendah dari Desa Ketenong II. Lebih lanjut Boer (2015a) menyatakan bahwa wilayah dengan kepadatan penduduk yang tinggi sangat sensitif terhadap bencana iklim seperti banjir, kekeringan dan tanah longsor. Hal yang sama terjadi pada desa-desa di Provinsi Nusa Tenggara Timur yang memiliki nilai indikator kepadatan penduduk yang tinggi (Boer, 2015a)

Desa Ketenong Jaya termasuk kategori rentan terhadap perubahan iklim. Desa ini memiliki indeks sensitivitas yang tidak tinggi. Hal ini disebabkan karena semua nilai indikator sensitivitas Desa Ketenong Jaya yang tidak tinggi kecuali indikator sumber air minum.

Desa Ketenong I dan Ketenong II termasuk kategori sangat rentan terhadap perubahan iklim. Kedua desa ini memiliki indeks sensitivitas yang tinggi. Desa Ketenong II memiliki indeks sensitivitas yang paling tinggi dibanding dengan desa - desa lain. Kedua desa ini memiliki indeks sensitivitas yang tinggi berasal dari indikator produksi padi sawah.

Untuk itu perlu dilakukan perbaikan tipe sawah dari dominan tipe sawah sederhana dan tadah hujan menjadi sawah semi teknis dan teknis agar tingkat kerentanan Desa Ketenong I dan Ketenong II berkurang dari kategori sangat rentan (SR) menjadi tidak rentan (TR).

\section{Kemampuan Adaptasi (AC)}

Kemampuan adaptasi dipengaruhi oleh aspek sosial, ekonomi dan infrastruktur. Jika aspek sosial, ekonomi dan infrastruktur suatu desa tinggi maka kemampuan adaptasi juga tinggi. Sebaliknya, jika aspek sosial, ekonomi dan infrastruktur suatu desa rendah maka kemampuan adaptasinya juga rendah.

Berdasarkan indeks kemampuan adaptasi (IAC), Desa Ketenong Jaya memiliki indeks kemampuan adaptasi yang paling tinggi $(11,271)$, diikuiti oleh Desa Air Kopras (10,785), Desa Ketenong I $(10,668)$, Desa Sebelet Ulu $(10,610)$, dan Desa Ketenong II $(10,583)$. Desa yang memiliki indeks kemampuan adaptasi (IAC) yang paling rendah adalah Desa Bioa Putiak $(10,424)$ dan Desa Tambang Saweak $(10,177)$.

Dari total desa-desa sekitar TNKS di Kecamatan Pinang Belapis Kabupaten Lebong, Desa yang memiliki indeks kemampuan adaptasi yang sangat tinggi $(14,25 \%)$, desa dengan 
indeks kemampuan adaptasi sedang $(28,6 \%)$, desa dengan indeks kemampuan adaptasi rendah $(28,6 \%)$ serta desa yang memiliki indeks kemampuan adaptasi sangat rendah $(28,6 \%)$ seperti terlihat pada gambar 4.4

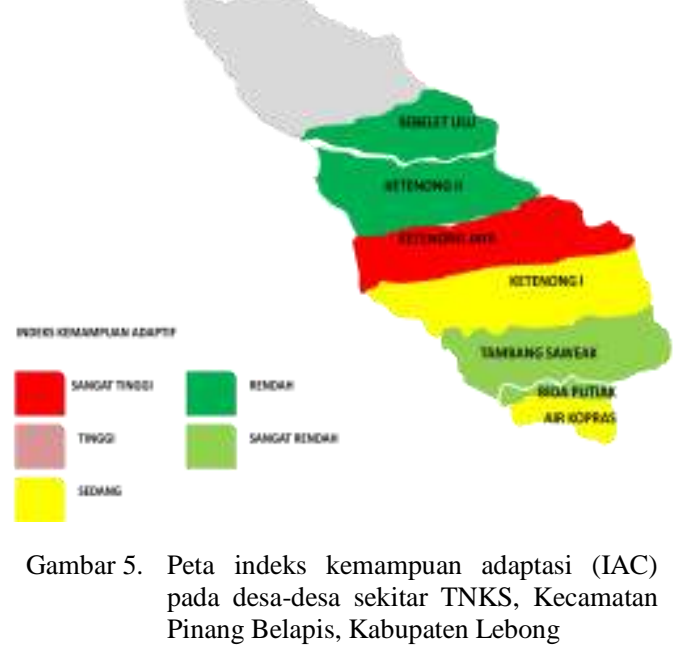

Desa Ketenong I dan Ketenong II termasuk kategori Desa yang sangat rentan terhadap perubahan iklim. Kedua desa ini memiliki indeks kemampuan adaptasi (IAC) yang rendah. Desa Ketenong I memiliki indeks kemampuan adaptasi (IAC) yang rendah berasal dari indikator fasilitas kesehatan, jumlah KK berdasarkan jenis rumah, dan indikator sarana dan prasarana pertanian Agar Desa Ketenong I dan Ketenong II dapat berubah dari kategori sangat rentan (SR) menjadi kategori tidak rentan (TR) terhadap perubahan iklim, maka perlu meingkatkan indeks kemampuan adaptasinya (IAC) pada indikator : 1) fasilitas kesehatan, 2) Jumlah KK yang memiliki jenis rumah non permanen (darurat), 3) sarana dan prasarana pertanian, 4) sarana pemasaran, 5) luas penanaman kopi, dan 6) infrastruktur jalan.

Hal tersebut dapat dilakukan dengan memperbiki infrastruktur fasilitas kesehatan, jalan, sarana pemasaran, sarana dan prasarana pertanian.
Diversifikasi sumber penghasilan selain padi sawah dapat meningkatkan pendapatan masyarakat.

Desa Ketenong Jaya termasuk kategori rentan terhadap perubahan iklim. Desa Ketenong Jaya memiliki indeks kemampuan adaptasi (IAC) yang lebih tinggi dibandingkan dengan desadesa lainnya. Indeks kemampan adaptasi (IAC) yang tinggi ini berasal dari indikator fasilitas kesehatan dan kelompok tani.

Desa Sebelet Ulu dan Desa Air Kopras termasuk kategori agak rentan terhadap perubahan iklim. Desa Sebelet Ulu dan air kopras tidak jatuh ke kategori sangat rentan dan rentan terhadap perubahan iklim karena kedua desa ini memiliki indeks kemampuan adaptasi (IAC) yang cukup tinggi pada indikator kontribusi pertanian terhadap PDRB.

Diversifikasi sumber penghasilan ini merupakan strategi untuk menanggulangi resiko kegagalan terhadap sebagian mata pencaharian. Penanaman kopi dan peternakan merupakan salah satu diversifikasi dari sumber pendapatan penduduk selain tanaman padi.

Desa Bioa Putiak dan Tambang Saweak termasuk dalam kategori tidak rentan terhadap perubahan iklim. Kedua desa ini memiliki indeks kemampuan adaptasi (IAC) yang tinggi pada indikator tingkat pendidikan, jumlah KK berdasarkan jenis rumah, jumlah KK berdasarkan jenis bahan bakar, jumlah KK berdasarkan sumber penerangan dan peternakan.

\section{KESIMPULAN}

Desa yang termasuk kategori sangat rentan terhadap perubahan iklim adalah Desa Ketenong I dan Ketenong II $(28,6 \%)$, desa yang termasuk kategori rentan terhadap perubahan iklim adalah Desa Ketenong Jaya (14.2\%), desa yang 
termasuk kategori agak rentan terhadap perubahan iklim adalah Desa Sebelet Ulu dan Air Kopras $(28,6 \%)$, dan desa yang termasuk kategori tidak rentan terhadap perubahan iklim adalah Desa Bioa Putiak dan Tambang Saweak $(28,6 \%)$

Alternatif upaya adaptasi terhadap perubahan iklim yang dapat dilakukan adalah :a) Memperbaiki Irigasi Tipe sawah menjadi Irigasi Semi Teknis dan Teknis serta pembangunan embung-embung, b) Mengurangi Kepadatan Penduduk, c) Memperluas Alternatif Diversifikasi Sumber Penghasilan Masyarakat (Non pertanian), d) Meningkatkan Fasilitas Kesehatan, e) Memperbaiki Infratruktur Jalan, Pemasaran dan Pertanian, f) Penguatan Kelembagaan Kelompok Tani.

\section{DAFTAR PUSTAKA}

(08 Februari 2018)

Agustine, D. 2018. Adaptasi petani sawah tadah hujan terhadap penurunan produktivitas padi (gagal panen) di jorong sungai salak kabupaten tanah datar. JOM FISIP Volume I (1) : 1-14

Boer, R., Perdinan, Faqih, A., Amanah, S., Rakhman, A., 2015a. Kerentanan Dan Pengelolaan Resiko Iklim Pada Sektor Pertanian, Sumberdaya Air \&Sumber Kehidupan Masyarakat Nusa Tenggara Timur. UNDP-SPARC Project. Kementerian Lingkungan Hidup dan Kehutanan. Jakarta

BPBD Provinsi Bengkulu. 2016. Kejadian bencana bulan januari - desember tahun 2012 - 2016 provinsi bengkulu. http://bpbd.bengkuluprov.go.id/kejadian -bencana-bulan-januari-desember-20122016-provinsi-bengkulu/html (06 Desember 2017)

BPS, 2017. Pinang Belapis Dalam Angka. Badan Pusat Statistik. Kabupaten Lebong Provinsi Bengkulu http://download.portalgaruda.org/article .php? article $=395067 \& \mathrm{val}=6435 \&$ title $=$ BUDIDAYA\%20TANAMAN\%20KO PI\%20UNTUK\%20ADAPTASI\%20D AN\%20MITIGASI\%20PERUBAHAN $\% 20 \% 20 I K L I M$ ( 10 Januari
Irawan, B. 2010. Dampak El Nino dan LA Nina Terhadap Produksi Padi dan Palawija.http://www.litbang.pertanian.g o.id/buku/politik-pembangunan/

Kementrian Lingkungan Hidup, GTZ dan WWF. 2010. Kajian Resiko Iklim dan adaptasi perubhan iklim pulau lombok Provinsi Nusa Tenggara Barat. http://awsassets.wwf.or.id/downloads/s ektor_pertanian.pdf

Peraturan Daerah Kabupaten Lebong Nomor 14 tahun 2012 Tentang Rencana Tata Ruang dan Wilayah Kabupaten Lebong Tahun 2012-2032. Pemerintah Kabupaten Lebong. Lebong

Sariffuddin, S., Astuti, Khristina Dwi., Farheni, Gustika., Wahdah, Lutfiyatul. (2017). Vulnerability Assesment : The Role of Coastal Informal Settlement Growth to Social Vulnerability in Genuk Sub-Distric, Semarang City. IOP Conference Series : Earth and Enviromental Science, 55(1), 012047. Doi :10.1088/1755-1315/55/1/012047

Sriwijaya Post. 2010. Pergeseran Awal Musim Kemarau Tahun 2010. http://palembang.tribunnews.com/29/06 /2010/pergeseran-awal-musimkemarau-tahun-2010 (15 Januari 2018)

Sukiyono, K., S.Widiono. and E. Apriyanto. 2013. Diversifikasi Ekonomi Rumah Tangga pada DesaDesa Sekitar Taman Nasional Kerinci Sebelat di Kebupaten Lebong Provinsi Bengkulu. AGRISEP Vol.13 (1) : 3140.

Supriadi, H. 2014. Budidaya Tanaman Kopi Untuk Adaptasi dan Mitigasi Perubahan Iklim. Jurnal Perspektif Volume 13 (1) :35-52.

WALHI BENGKULU. 2008. Kerusakan Hutan Taman Nasional Kerinci SebelatWilayah Kabupaten Lebong, Propinsi Bengkulu. Diunduh dari http://cfors.wordpress.com/2008/03/14/ kerusakan-hutan-taman-nasionalkerinci-sebelat-wilayah-kabupatenlebong-propinsi-bengkulu pada tanggal 17 Juli 2011, jam 11.00 
